\title{
家后囬粘膜よりのウラニン忣收に及ぼす \\ ヒアルロニダーゼの効果
}

\author{
京都府立医科大学耳鼻咽喉科学教堂（主任 中村交雄- 教授）
}

石原雄

\section{緒言}

鼻腔に塗布あるいは噴第㫡された薬剤がその簓所で効果を現わすためには用いた薬剤がなるべく多 量その局所組織に浸透吸収されることが必裂である。そのためには薬剤の拡散度を增加するのと組 織の透過性をたかめるのとの三つの方法がある. しかし前の方法は各種の薬剤に定まつた溶解度， 拡散度があつてこれを容易に変えることはできない。これは私の轒粘膜よりのアセトスルフアミン の吸収実験でも明らかである。そこで後の方法ということになる。これには1928年末 Duran-Reynals および McClean 等の努力で進展された拨散因子の研究が1940年 Chain \& Duthie によりヒ アルロニターゼなる酵素の発見をもたらしたが，この酵素を用いて局所組織の透過性を昂めて悬内 適用物質の拡散を速めるという方法がある。そこで私はウラニンなる色素を轒内に用いて，それに 該酵素を加えて吸収実験を行い色素の吸収がいかに変るかを調べた。

\section{実験材料および実験方法}

$2 \mathrm{~kg}$ 前後の家鬼を背位に固定し, 気管切開を行つた 後, 鼻咽頭腔より㗹頭扣よび食道の入口部にわたりワ セリンを浸したガーゼを充媜しかつ気管切開口の直ぐ 頭側で食道と気管を一緒に結紫して, 色素液の気管あ るいは食道への流入を防ぎ, 武田薬品工業製のヒアル ロニダーゼ 50 単位 $の$ 溶液中に $2.5 \%$ の割合でウラニン
を溶解したりの $0.5 \mathrm{cc}$ を左右鼻腙に各々 $2.5 \mathrm{cc}$ 宛約 30 秒を要して滴下するよ5に注入し，注入し終つてから 5 分， 30 分，120分，180分後に夫々採血を行い，これ より遠心沈澱によつて得て血清中の色素濃度をプルフ リッヒの比色計で比色定量して，ヒアルロニダーゼを 添加しないるのの血清中色素濃度と比較した.

\section{実 験 成 績}

第 1 表抢よび第 2 表の比色計のよみより第 1 図によ り第 1 表扣よび第 2 表の血清中色素濃度ができ上る. 第 1 表は䣼素を加えてないるの，第 2 表は醉素を加え てあのであつて個々の值は表に示す通りである。耐者 の平均值を図に示すと第 2 図のごとくなる.

つぎに醉素を加えたるのと対照とを平均値の時間的 経過の型の上で比較してみると計算式の主要部は (I) $\alpha \beta=10^{-4}\left(\begin{array}{rrrrr}108 & -29 & 74 & 130 & 156 \\ -29 & 532 & 69 & -272 & -128 \\ 74 & 69 & 262 & 212 & 60 \\ 130 & -272 & 212 & 1190 & 1329 \\ 156 & -128 & 60 & 1329 & 2174\end{array}\right)$

$$
\begin{aligned}
& 4 \propto \alpha \beta=\frac{10^{7} \times 10^{-16}}{2782889 \times 10^{5} \times 10^{-20}} \\
& \left(\begin{array}{rrrrr}
4075 & 745 & -1898 & 890 & -740 \\
745 & 1139 & -1258 & 1100 & -624 \\
-1898 & -1258 & 3266 & -1988 & 1187 \\
890 & 1100 & -1988 & 2143 & -1254 \\
-740 & -624 & 1187 & -1254 & 878
\end{array}\right) \\
& \left\{D_{1}=10^{-4}(-3.6,-7.5, \quad-0.8, \quad 1.8,6.0)\right. \\
& \mathrm{M}=5 \quad \mathrm{~N}=5 \quad \mathrm{n}_{1}=\mathrm{k}=5 \quad \mathrm{n}_{2}=4 \\
& \text { Fo }=\frac{9 \times 25 \times 0.668}{5 \times 10}=3.005>2.48(20 \%) \text { となつ } \\
& \text { て } 80 \% \text { の信頼度で両者の経過の型に差があると認め }
\end{aligned}
$$


第 1 表

\begin{tabular}{|c|c|c|c|c|c|c|c|c|c|c|c|c|}
\hline \multirow{2}{*}{$\begin{array}{cc}\text { 头 } & \text { 験 } \\
\text { 月 } & \text { 日. }\end{array}$} & \multirow{2}{*}{$\begin{array}{c}\text { 体棗 } \\
\mathrm{kg}\end{array}$} & \multirow{2}{*}{ 性 } & 比 & 色 & 計 & 読 & म & 色 & 素 & 濃 & \multicolumn{2}{|c|}{$(\mathrm{mg} \%)$} \\
\hline & & & “5 分 & 30 分 & 60 分 & 120分 & 180分 & 5 分 & 30分 & 60分 & 120 分 & 180 分 \\
\hline 6/XI & 2.0 & 우 & 0.001 & 0.0335 & 0.036 & 0.038 & 0.0495 & 0.01 & 0.32 & 0.34 & 0.37 & 0.48 \\
\hline 17/XI & 1.8 & 㑒 & 0.010 & 0.0135 & 0.0345 & 0.0625 & 0.077 & 0.1 & 0.13 & 0.33 & 0.6 & 0.74 \\
\hline $20 / X I$ & 1.7 & 우 & 0.001 & 0.019 & 0.0315 & 0.0635 & 0.080 & 0.01 & 0.18 & 0.3 & $\cdot 0.61$ & 0.77 \\
\hline $24 / X I$ & 2.2 & 客 & 0.0045 & 0.0155 & 0.029 & 0.0425 & 0.059 & 0.04 & 0.15 & 0.28 & 0.41 & 0.57 \\
\hline 6/XII & 1.9 & 含 & 0.002 & 0.016 & 0.0235 & 0.027 & 0.0315 & 0.02 & 0.15 & 0.22 & 0.26 & 0.3 \\
\hline & & 半 & & & & & & \begin{tabular}{|l}
0.03 \\
\pm 0.03
\end{tabular} & $\begin{array}{c}0.18 \\
\pm 0.06\end{array}$ & $\mid \begin{array}{c}0.29 \\
\pm 0.04\end{array}$ & $\begin{array}{c}0.45 \\
\pm 0.13\end{array}$ & \begin{tabular}{|l}
0.57 \\
\pm 0.17
\end{tabular} \\
\hline
\end{tabular}

第 2 表

\begin{tabular}{|c|c|c|c|c|c|c|c|c|c|c|c|c|}
\hline \multirow{2}{*}{$\begin{array}{cc}\text { 実 } & \text { 験 } \\
\text { 月 } & \text { 日 }\end{array}$} & \multirow{2}{*}{$\begin{array}{c}\text { 休重 } \\
\mathrm{kg}\end{array}$} & \multirow{2}{*}{ 性 } & 比 & 色 & 計 & 読 & म & 色 & 素 & 濃 & \multicolumn{2}{|c|}{$(\mathrm{mg} \%)$} \\
\hline & & & 5 分 & 30 分 & 60 分 & 120 分 & 180分 & 5 分 & 30 分 & 60分 & 120分 & 180 分 \\
\hline $28 / \mathrm{VII}$ & 1.8 & 占 & 0.0135 & 0.0335 & 0.0405 & 0.0435 & 0.0535 & 0.13 . & 0.32 & 0.39 & 0.42 & 0.52 \\
\hline $30 / \mathrm{VII}$ & 2.2 & 우 & 0.0055 & 0.014 & 0.0325 & 0.045 & 0.0515 & $0.05^{\circ}$ & 0.13 & 0.31 & 0.44 & 0.5 \\
\hline $3 /$ VII & 2.0 & 古 & 0.004 & 0.032 & 0.0335 & 0.040 & 0.047 & 0.04 & 0.31 & 0.32 & 0.39 & 0.45 \\
\hline $6 / \mathrm{VIII}$ & 2.2 & 古 & 0.0085 & 0.0225 & 0.029 & 0.059 & 0.0745 & 0.08 & 0.22 & 0.28 & 0.57 & 0.72 \\
\hline $8 /$ VII & 1.9 & 무 & 0.006 & 0.034 & 0.022 & 0.035 & 0.038 & 0.06 & 0.33 & 0.21 & 0.34 & 0.37 \\
\hline & & 4 & & & & & & $\begin{array}{c}0.07 \\
\pm 0.03\end{array}$ & $\begin{array}{c}0.26 \\
\pm 0.07\end{array}$ & $\begin{array}{c}0.30 \\
\pm 0.06\end{array}$ & $\begin{array}{c}0.43 \\
\pm 0.08\end{array}$ & $\begin{array}{c}0.51 \\
\pm 0.12\end{array}$ \\
\hline
\end{tabular}

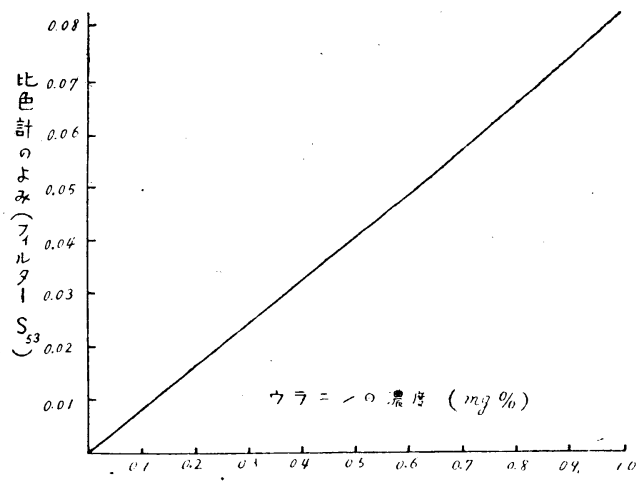

第 1 図 ウラニン比色定量規準直線

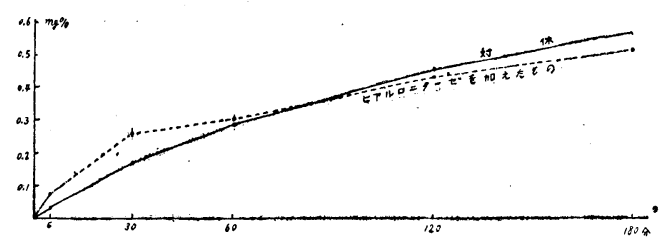

第 2 図

\section{考按}

第2図をみると 5 分, 30 分, 60 分において血清 中の色素濃度は対照に比してや子高くなつてい る. 120 分, 180 分では対照上りわずか低くな つているが，これは始めの方で多量に吸収され た悬内约存する色素液の濃度低下が抎散の減少 をもたらしたものと教られる.すなわちヒア ルロニダーゼを涯加したものは始めの方でよく 吸収されているといらことになる。

ヒアルロニターゼを粘膜表面より用いて吸収 を調べた実験は見ないが,これは該酵素が Berkefeld の憈過器は通過するが, 半透膜は通過し ないので可なり高分子量を有するものと考六ら れているからであらう。

そこで一般に半透膜と考兄られている動物膜 である鼻粘膜を通過するかどうかという問題で あるが，これは自然に存在ずる動物嗼は撖密に 半透膜ではなくところどころにかなり大きな孔

があり，相当大きな粒子をも通過せしめることは私がゴロイドであるコンゴーロートを以てそれが 
鼻粘膜を経て农収が行われることを明らかにした䨋験からでもよくわかる。

それで少量ではあるがヒアルロニターゼは䙹粘膜を経て侵入し，結合組織中のヒアルロン酸を加 水分解してその粘稠度を減じ，そのため組織の透過性を昂め僅かながらウラニンの吸収を促進した ものと考えられる.

\title{
結論
}

ヒアルロニターゼ添加によりウラニンの家鬼の経鼼粘膜吸収は僅か乍ら始めのすで促進される が, 分子量が大であるためその効果はそれ程著明ではない。

稿を終るにのぞみ，御等篤なる御指導を睗わり御校閲を頂いた中村交雄教授に梁謝す。 本論交の要旨は第 9 回近畿耳鼻咽㥄科学会の席上で報告した。

\section{主 要 交 献}

1) 不原 : 色素の経鼻粘膜吸収に関する然験的研究

- 京府大誌, $51 ; 4$.
2) 加来 : 医学鐘書 43

3) 楖原：同 53

\section{寒泠の家鬼乳突起創傷におよぼす影響}

\author{
北海道大学医学部耳鼻咽喉科教室（主任 猿渡二郎 教授）
}

三 部 重 喜

\section{緒言}

創傷に影響すべき因子はきわめて多数存在し，乙かもこれらは完全に独立的に治癒に関係する事 はきわめてまれであり，多くの場合はおのおの関連して複雑な影響を与えるものである. 元来生体 は極めて旺盛なる再生機能を有しているすので創傷はこれに依り自然的治癒を営み得るものであ り,外界よりの影響はこれに促進的に㗢きあるいは抑制的に働くものである.これら創傷治癒を促進 しあるいは遷延せしめる諸因子について臨床的, 实験的に多くの研究がなされて来る. しかし寒冷 が全身的に影響を与えた時の創傷治癒に関して恃全く研究されていない，たまたまわが北海道大学 は本邦最北端に位し，その地理的関係より諸種の聅患特に耳鼻咽喉科領域においては寒冷により影 響されることがきわめて多く，わが教室は猿渡教授指尊のもとに過去十数年間本問題の研究に従事 し, すでに多くの研究成果の発表があり, 昭和 25 年 5 月第 51 回日本耳鼻咽喉科学会に打いて猿渡 教授により宿題報告として発表されている.なお一般生体に対する低温の影響に関しては本学柳教 授により詳細なる発表がある。私は猿渡教授指導の下に本研究の一環として低温の家兔乳様突起創 傷に及ぼす影響について実験的に研究した。

\section{実 験 方 法}

使用動物：白色雄性家鬼（体重 $2 \mathrm{~kg}$ 前後）を選び，

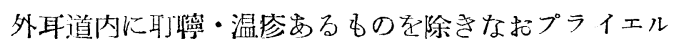

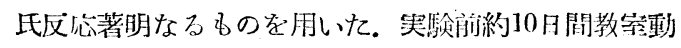
物室にて飼育し佔用に供して。
使用細菌：黄色榺蒛状球菌（寺島株）浮遊液を作製 （木菌 1 エーゼを $5 \mathrm{cc}$ 隇藏溜水に溶解）し使用した。 低温感作济: つぎの 3 群に分け低温感作を行つた。 A 洋 : 手術解24特間感作: (以下A样とす) 